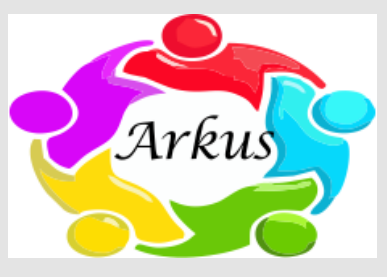

\title{
ARKUS
}

Journal Homepage:

https://hmpublisher.com/index.php/arkus

\section{The Effect of Cupping Therapy on Pain Degree in Athralgia}

\section{Kusworini 1*}

${ }^{1}$ Department of Pharmacology, Faculty of Medicine, Universitas Brawijaya, Malang, Indonesia

\author{
A R T I C L E I N F O \\ Keywords: \\ Cupping therapy \\ Vacuum \\ Hot temperature \\ Pain \\ Arthralgia
}

\section{Corresponding author:}

Kusworini

E-mail address:

\section{kusworinik20@gmail.com}

The author has reviewed and approved the final version of the manuscript.

https://doi.org/10.37275/arkus.v7i2.97

\begin{abstract}
A B S T R A C T
Joint inflammation characterized by swelling of the joints, redness, heat, pain and movement disorders. Arthralgia causes the elderly to have difficulty in carrying out activities that are burdening the joints of the body. Wet cupping therapy is a complementary therapy that has a working principle of vacuum, injury and bloodsucking in certain areas so it can cure the disease. This study was to identify the effect of cupping therapy on pain intensity in elderly patients with arthralgia in Malang. It was a quasy experiment research with pretest-posttest with control group approach. The sample in this study was 30 elderly then divided into two groups, i.e. 15 elderly in the wet cupping therapy group and 15 elderly in the warm compress group. It used purposive sampling. The average pain intensity before moist cupping therapy was 7.47 , and after wet cupping therapy 5.53 . While the moderate pain intensity before warm compress was 7.00 and after warm compress 5.73. Wilcoxon test results moist cupping therapy obtained P-value 0.001 means there are significant differences before and after the wet cupping therapy. While Wilcoxon test results, warm compress got P-value 0.001 means there are substantial differences before and after the warm compress. Mann Whitney test result obtained P-value 0.383 means there is no significant difference of effect between the treatment group and the control group. There is an effect of cupping therapy and warm compress on pain intensity. Elderly can use wet cupping therapy as an alternative treatment to decrease joint pain intensity arthralgia.
\end{abstract}

\section{Introduction}

Joint pain is an inflammation of the joints characterized by joint swelling, redness, heat, pain and movement disorders. ${ }^{1}$ The ageing process causes a decrease in muscle tone, stiffness and resistance of the musculoskeletal system. Joint stiffness decreases joint movement. Elderly with the degenerative joint disease will complain of experiencing joint stiffness in the morning with limited joint motion, and pain in muscles. ${ }^{2}$

Joint pain causes impaired physical capacity, namely the presence of pain in the knee, limited range of motion of the joint, decreased joint muscle strength, and difficulty in carrying out activities that are burdensome to the knee joint. If allowed to get worse and cause pain every time you make specific movements and inflammation of the joints. ${ }^{3}$ Based on Basic Health Research, the prevalence of elderly suffering from a joint disease in Indonesia is $24.7 \%$. A higher majority occurred in women (13.4\%) than men $(10.3 \%)$.

Joint pain requires treatment, both pharmacologically and non-pharmacologically. One of the pharmacological therapies is by giving antiinflammatory drugs. However, the use of medications continuously can cause side effects for the elderly. Therefore, the management of joint pain can be done 
with non-pharmacological treatment, one of which is by giving cupping therapy. ${ }^{4,5}$

Cupping is a treatment model with the principle of cleaning blood from causative pathological substances (CPS) which includes metabolic waste, toxins, particles that cause pain, cholesterol, uric acid, excess glucose, and inflammatory cells in the body that are secreted through the skin surface. Blood circulation in the joints, thereby preventing swelling of the synovial membrane which causes changes in joints. ${ }^{6}$ This study was conducted to determine the effect of cupping therapy on pain scales in older people experiencing joint pain.

\section{Methods}

This study used a quasi-experimental design with a pretest-posttest with control group design involving thirty participant Malang Elderly Posyandu then divided into two groups, namely the treatment group (cupping therapy) and the control group (warm compress). Selection of research subjects using nonprobability sampling with purposive sampling. The inclusion criteria were older people aged more than 60 years who experienced joint pain. The study was conducted in June 2017. Standard operating procedures (SOP) for cupping were carried out at 7 points including 1 point Al-Kaahil area, 2 points hind thigh, 2 point folds of the knee and 2 points Assaqo' in (calf) by bleeding dirty blood. From inside the body through the surface of the skin with three co-ops in 1 intervention. ${ }^{7}$

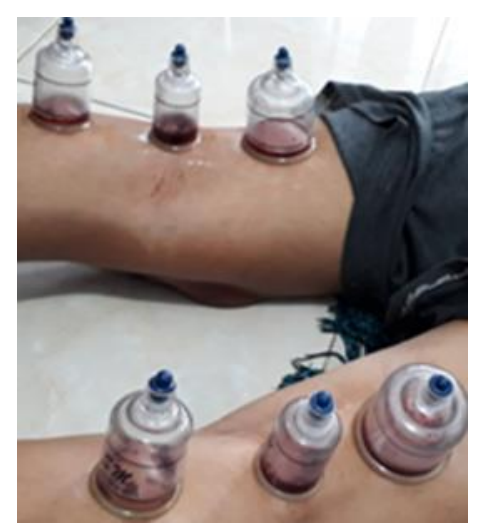

Figure 1. Several points are used

While the warm compress is applied to the front knee with a temperature of $46^{\circ} \mathrm{C}-51.5^{\circ} \mathrm{C}$ for 20 minutes. 8 The demographic data sheet consisting of characteristics includes name, gender, age, education level, and occupation. The instrument is a numerical pain scale sheet.

The stages in this study include a conceptual framework consisting of input, which is by the inclusion criteria, the process in the form of the implementation of the cupping SOP, the output in the format of intervention results. Data collection procedures include administrative procedures, technical procedures and data collection instruments. Data analysis was performed computerized using the Wilcoxon test and Mann Whitney test with a significance level of 5\% (0.05), and Levene's test to determine the homogeneity of the variables.

\section{Results}

General data consists of respondent characteristics based on gender, age, education level and occupation. Specific data consist of pain scales before and after cupping therapy (treatment group) when compared with the results of pain scales before and after warm compresses (control group). Characteristics of elderly based on gender in Malang showed that the majority of older women in the 
treatment group were ten elderly $(66.7 \%)$ in the control group 11 elderly (73.3\%).

Characteristics of elderly based on age in Malang showed that most of the elderly aged 60-70 years in the treatment and control groups respectively were 13 elderly (86.7\%). Characteristics of elderly based on education level in Malang shows that most of the elderly with the latest education level are $\mathrm{SD}$ in the treatment group as many as seven elderly (46.7\%) in the control group 6 elderly (40\%). The characteristics of the elderly based on occupation indicate that the majority of the elderly work as traders in the treatment and control groups as many as five elderly $(33.3 \%)$.

Table 1. Pain scale in the elderly before cupping therapy and warm compresses

\begin{tabular}{lcccc}
\hline Pain scale & $\begin{array}{c}\text { Treatment group } \\
\text { (n) }\end{array}$ & Percentage (\%) & $\begin{array}{c}\text { Control group } \\
(\mathrm{n})\end{array}$ & Percentage (\%) \\
\hline Scale 6 & 3 & $20 \%$ & 4 & $40 \%$ \\
Scale 7 & 5 & $33,3 \%$ & 7 & $46,7 \%$ \\
Scale 8 & 5 & $33,3 \%$ & 4 & $26,7 \%$ \\
Scale 9 & 1 & $6,7 \%$ & 0 & $0 \%$ \\
Scale 10 & 1 & $6,7 \%$ & 0 & $0 \%$ \\
\hline Total & 15 & $100 \%$ & 15 & $100 \%$ \\
\hline
\end{tabular}

Source: Primary data, 2019

The table above shows the results that most of the elderly before cupping therapy in the treatment group experienced a pain scale of 7 and 8 respectively as many as five elderly (33.3\%) before doing warm compresses in the control group experienced a pain scale of 7 as many as seven elderly (46,7\%). Joint pain is a joint inflammation characterized by joint swelling, redness, heat, pain and movement disorders.

The pain experienced by the elderly is generally

Table 2. Pain scale in the elderly after cupping therapy and warm compress

\begin{tabular}{|c|c|c|c|c|}
\hline Pain scale & $\begin{array}{l}\text { Treatment group } \\
\text { (n) }\end{array}$ & Percentage (\%) & $\begin{array}{l}\text { Control group } \\
\text { (n) }\end{array}$ & Percentage (\%) \\
\hline Scale 4 & 1 & $6,7 \%$ & 3 & $6,7 \%$ \\
\hline Scale 5 & 7 & $46,7 \%$ & 2 & $46,7 \%$ \\
\hline Scale 6 & 6 & $40 \%$ & 6 & $40 \%$ \\
\hline Scale 7 & 0 & $0 \%$ & 4 & $46,7 \%$ \\
\hline Scale 8 & 1 & $6,7 \%$ & 0 & $0 \%$ \\
\hline Total & 15 & $100 \%$ & 15 & $100 \%$ \\
\hline
\end{tabular}

Source: Primary data,

not assessed and cannot be intervened because the elderly think that pain is part of the ageing process. The process of ageing causes a decrease in muscle tone, stiffness and resistance of the musculoskeletal system. Joint stiffness and erosion decrease joint movement. Elderly with the degenerative joint disease will complain of experiencing joint stiffness in the morning with limited motion, and muscle pain. ${ }^{2}$ 
Table 2 shows the results that most of the elderly after cupping therapy in the treatment group experienced pain scale five as many as seven elderly
(46.7\%) before doing warm compresses in the control group experienced pain scale six as many as six elderly $(40 \%)$.

Table 3. Pain scale in the elderly after cupping therapy and warm compress

\begin{tabular}{|c|c|c|c|c|c|}
\hline & $\begin{array}{l}\text { Amount } \\
\text { (n) }\end{array}$ & Maximum & Minimum & Mean & Std. Deviation \\
\hline Before cupping therapy & 15 & 10 & 6 & 7.47 & 1.125 \\
\hline Before warm compress & 15 & 8 & 6 & 7.00 & .756 \\
\hline After cupping therapy & 15 & 8 & 4 & 5.53 & .915 \\
\hline After warm compress & 15 & 7 & 4 & 5.73 & 1.100 \\
\hline$P$ value $=0.001$ & & & & & $a=0.05$ \\
\hline
\end{tabular}

Table 4. Differences in the effect of cupping therapy and warm compress on pain scale in elderly experiencing joint pain

\begin{tabular}{llllll}
\hline & Participants & N & Mean Rank & Sum of Ranks & Sig (2-tailed) \\
\hline Pain Scale & Cupping therapy & 15 & 14.17 & 212.50 & 0.383 \\
& Warm compress & 15 & 16.83 & 252.50 & \\
\hline Total & & 30 & & &
\end{tabular}

Source: Primary data, 2019

Table 5. Differences in the effect of cupping therapy and warm compress on pain scale in elderly experiencing joint pain

\begin{tabular}{llcccc}
\hline & Participants & N & Mean Rank & Sum of Ranks & Sig (2-tailed) \\
\hline Pain scale & Cupping therapy & 15 & 14.17 & 212.50 & 252.50 \\
& Warm compress & 15 & 16.83 & & 0.383 \\
\hline
\end{tabular}

Source: Primary data, 2019

\section{Discussion}

First step of cupping, liquids and harmful substances begin to accumulate in the cupping area. These chemical substances, inflammatory mediators, and pain mediators that melt away will pool the sensory nerve endings in the cupping area and break the adhesions of the tissue, which will reduce pain. 9 The insertion in the cupping area opens the skin barrier to remove fluid along with harmful substances. This stabbing will ultimately result in increased clearance of the blood plasma of disease- causing materials, such as toxins, pain-causing particles, and other harmful substances. After the negative pressure stabbing using cupping is done again in the area. This second negative pressure causes all the collected liquid (along with harmful substances) to come out until all the liquid that has collected in the cupping area runs out. Because there is a considerable pressure gradient on the addition of this second cupping at the ends of the arterioles and venules it will cause filtration at both ends of the capillaries. ${ }^{9}$ Puncture during cupping therapy will 
increase the release of nitric oxide. Blood flow to the subcutaneous area where the Puncture is carried out increases, this is in line with the production of nitric oxide, which will increase in areas of high circulation. Increased production of nitric oxide is also reported to increase when the skin is injured.

After cupping therapy, the elderly with joint pain will experience a decrease in the pain scale. This fact occurs because of the primary mechanism of cupping by doing clamping at the point: Al Kaahil, located at the intersection of the shoulder line with the midline of the body, namely the spine (processus spinosus cervicalis VII) at the shoulder height, the point of the hamstrings four fingers above the knee crease, the point of the folded knee, and the three-finger Assaqo' in (calf) point below the knee crease.

Based on the results of the Wilcoxon test analysis, it was found that the sig (2-tailed) value of cupping therapy $=0.001$, meaning that there was a difference before and after cupping therapy was carried out. The mean value after cupping therapy was 5.53, which was smaller than the average value before cupping therapy 7.47 . While the sig (2-tailed) warm compress $=0.001$ means that there is a difference before and after a warm compress. The average value after the warm compress was 5.73 smaller than the average value before the warm compress at 7.00 .

Cupping therapy plays a role in removing prostaglandins that are formed due to cell inflammation. This substance serves to send pain signals to the brain. Through the process of cupping this substance is released so that the pain felt by the elderly is reduced. Cupping stimulates the release of endorphins and encephalins, which play a role in reducing sensitivity to pain. Both of these substances are released due to mild pain due to suction and incision from the cupping device. Another substance released during the cupping process is the release of nitric oxide, this substance is responsible for most of the improvement in health conditions that occur after cupping, including vasodilation of blood vessels, increasing the supply of nutrients through capillaries and arteries throughout the body's tissues. 10

Biologically warm compresses can cause dilation of blood vessels resulting in increased blood circulation. Physiologically, the body's response to heat causes dilation of blood vessels, decreases blood viscosity, decreases muscle tension, increases tissue metabolism and capillary permeability. 11

Factors that influence the intensity of a person's pain include age. Generally, the older, the more the tolerance to pain. This study showed that most of the elderly aged 60-70 years in the cupping therapy group were $13(86.7 \%)$ aged 60-70 years, while in the warm compress group 13 (86.7\%) were 60-70 years old.

The data variant of the two groups based on the pain scale after cupping therapy and warm compresses $=0.386$ means that between the two groups has the same variant with the most pain scale six and an average of 5.6. While the data variant based on age $=0.879$ means that between the two groups has the same variant with the most age 60 and an average of 66.

At the age of over 60 years, degenerative diseases of the knee begin to occur due to damage to joint cartilage. Patients in the early stages will complain of joint stiffness in the morning along with pain in the knees, especially when squatting, standing, or going up and downstairs and end with limited joint motion which sometimes forces the sufferer not to walk even though the body is still relatively healthy. 3

The results of the Mann Whitney test showed that the sig (2-tailed) value of cupping therapy and warm compresses $=0.383$ means that there is no difference in the effect of cupping therapy and warm compresses on the pain scale.

Another factor that influences pain is a cultural value; the cultural background is a factor that affects the reaction to pain and the expression of pain. An unfamiliar environment and the high activity in that 
environment can aggravate pain. Support from family and loved ones is one of the critical factors influencing individual pain perception. Stress often accompanies a painful event. Threats of unknown origin and inability to control pain. ${ }^{12}$

\section{Conclusion}

There is an effect of cupping therapy on the pain scale of the elderly who experience joint pain in Malang There is no difference in the effect of cupping therapy and warm compresses on the scale of pain in the elderly who experience joint pain in Malang.

\section{References}

1. Handono S, Richard SD. Efforts to Reduce the Knee Joint Pain Complaints in Elderly Elderly Posyandu Prosper. J Penelit STIKES Kediri. 2013; 6(1): 63-73.

2. Dewi SR. Buku Ajar Keperawatan Gerontik. Yogyakarta. 2014.

3. Susilawati I, Tirtayasa K, Lesmana SI. Latihan Closed Kinetic Chain Lebih Baik Dari Pada Osteoarthritis Lutut Setelah Pemberian Micro Wave Diathermy (MWD) Dan Transcutaneus Electrical Nerves Stimulation (TENS). Sport Fit J. 2015; 3(1): 26-34.

4. Kemenkes RI. Riset kesehatan dasar 2013. Jakarta Badan Penelit dan Pengemb Kesehatan. 2013.

5. El Sayed SM, Mahmoud HS, Nabo MMH. Methods of wet cupping therapy (Al-
Hijamah): in light of modern medicine and prophetic medicine. Altern Integr Med. 2013: 1-16.

6. Kurniawan D, Uda M. Effect of changes cupping therapy in the elderly with joint pain rheumatoid atrtritis (study in UPT PSLU jombang). J Keperawatan. 2013; 5(1).

7. Widada W. Terapi Bekam Solusi Cerdas Mengatasi Radikal Bebas Akibat Rokok. 2011.

8. Kurniawati I. Efektifitas Terapi Bekam terhadap Penurunan Skala Nyeri Dismenore pada Mahasiswi Program Studi S1 Keperawatan Universitas Muhammadyah Jember. 2016.

9. Larasati TA, Wicaksono TD. Mekanisme Bekam sebagai Terapi Alternatif dalam Menurunkan Hipertensi. J Major. 2016; 5(2): 112-119.

10. Ramadhani G. Efektifitas Terapi Bekam pada Area Pinggang terhadap Penurunan Nyeri Pinggang di Holistic Nursing Therapy Probolinggo. 2016.

11. Anugraheni V, Wahyuningsih A. Efektifitas Kompres Hangat dalam Menurunkan Intensitas Nyeri Dyshmenorhea pada Mahasiswi STIKES RS Baptis Kediri. $J$ STIKes. 2013; 6(1): 12-16.

12. Mubarak WI, Chayatin N. Buku ajar kebutuhan dasar manusia: Teori dan aplikasi dalam praktik. Jakarta: Media Aesculapius. 2008. 